naphthalene flakes, liberally distributed in and about the spaces occupied by the bats. A third method is the destruction of the bats by fumigation with, say, hydrocyanic acid generated from calcium cyanide; but the procedure is dangerous and demands handling by an expert, and it has the disadvantage of leaving the dead bodies of the bats to decompose and add to the odours of the roost.

\section{The Albert National Park in the Belgian Congo}

ON November 12, 1935, a decree was passed which doubled the area of what was already one of the most remarkable natural reserves in the world, the Parc National Albert du Congo Belge. The extension, carrying the park northward and westward to Lake Edward which it incorporates, increases the area of the reserve from 390,000 hectares to 856,790 hectares, and its average length and width to $270 \mathrm{~km}$. and $40 \mathrm{~km}$. respectively. Within this area, the greatest diversity of habitat is to be found, for it stretches from the equator to the extreme east of the Belgian colony, and rises from 850 metres in the Semliki Plain to 5,119 metres at Peak Marguerite. As a consequence, the region now included presents a succession of stages of vegetation from primitive tropical forest to the equatorial alpine zone, and in plants and animals contains a rich flora and fauna comprising many forms not elsewhere to be found. The value of the new extension is the greater since the Belgian reserve is contiguous with the British Uganda reserve, and ought to permit the adoption, through an extensive area in which the needs of the fauna and flora are similar, of common protective measures, such as were contemplated in the London Convention of November 1933 (Article 6) relative to the conservation of the natural fauna and flora, to which Belgium signified her adhesion.

\section{Soil and Forest Conservation in the United States}

The United States has now awakened to the serious position brought about by the excessive felling and destruction of forests during the last fifty years. A great campaign is taking place with the object of impressing upon the people the valuable results to be expected from soil conservation and forest conservation, which are now regarded as national problems. The work of Mr. C. A. Connaughton of the U.S. Forest Service is commented upon in a recent communication from Science Service, Washington, D.C. This investigator has studied more than 3,000 test plots in burnt-over forest land, comprising both cut-over areas and virgin timber. In genoral, the more severe the fire the more severe also was the subsequent erosion. On the steeper lands, lightly burnt areas, on which the fire took only the top layer of the forest floor litter (the ordinary leaf fire, so termed), little erosion was perceivable, about 10 per cent of such plots being eroded. In the case of severe fires, so high as 80 per cent of the plots showed erosion. Mr. Connaughton's research would appear to merit attention from officers connected with these matters in the British Empire. "Of course," says the author, "where soil is eroded away from a burnt-over forest site, it is difficult to make trees grow there again-impossible, if the erosion is severe enough to lay bare the underlying rock. But the damage is apt to be felt by people who never see or think about the forests. Hundreds of miles away, the freshets that gush through the erosion gullies accumulate as floods, in the greater rivers, piling out of their banks to wreak destruction, and leaving behind them, on lowland farms and industrial areas, burdens of silt that should be up in the hills, growing trees." This might have been written in connexion with the outer Punjab hills. The paper is given in full in the current issue of the Journal of Forestry.

\section{Efficiency of Wood as Fuel}

IN an age of so much and such abstruse research, it is common to find that no exact answer can be given to some of the most everyday problems. The Canadian Department of Mines found this to apply to the relative value of wood as domestic fuel as compared with coals. In Canada, this question has an importance which has long since disappeared in Great Britain. The Fuel Division of the Department has published tests by E. S. Malloch and C. E. Baltzer (Report No. 761, Ottawa, 10 cents) on the efficiency of wood as fuel for heating water in a furnace of the type normal in North America, and previously used for tests on coal and coke. Tests with an American anthracite showed a thermal efficiency of 66 per cent. Under comparable conditions, the efficiency of hardwood (maple) varied from 50 per cent (green) to 57 per cent (seasoned wood). Corresponding figures for soft wood (pine) were 42 per cent and 49 per cent. By placing a perforated plate over the firebars, the efficiency could be slightly increased, and in all cases the loss in unburnt fuel was negligible. These figures are quite good, but the wood compared unfavourably with coals in output and in the weight and volume of fuel to be handled.

\section{San Francisco Bay Bridge}

THE project of building a bridge across San Francisco Bay was first discussed seventy-five years ago. Photographs of the bridge now under con. struction given in the Electrician of February 14 show that it is nearing completion. The twin suspension bridges are the largest in the world and are attached to hollow concrete anchorages about 280 feet above the water. The centre towers are 519 feet high and the outer ones 474 feet. The main spans of the twin suspension bridges are 2,310 feet long and the side spans 1,610 feet. A tunnel through Yerba Buena Island connects the two halves of the bridge. The eastern half of the bridge has a cantilever span 1,400 feet long which is still uncompleted. The bridge is to cost $£ 15,500,000$, and is being built for the California Toll Bridge Authority. The bridge will be lighted by the largest installation of sodium vapour lamps in the world; they are arranged along the fifteen miles of roadways for the double deck spans, the tunnel and the approaches at the San Francisco and 
Oakland ends. On the upper deck of the bridge, to be used for six lines of passenger vehicles and other high-speed traffic, the illumination will be specially bright. A new type of reflector is used with the lamps which does not oxidise, has a very hard surface and has a reflecting factor of more than eighty per cent. Six 1,000-watt single lens rotary beacons and five 400-watt flashing beacons will warn aircraft of the proximity of the bridge. A large number of navigational lights will be required and fog warnings will be given by five large bells and six fog sirens driven by ten horse-power motors.

\section{Significance of Classification of Organisms}

THe study of form has revealed the importance of convergence in the evolution of plants and animals, as well as the inevitable influence of laws of growth which apply to creatures whatsoever their descent. But the significance of convergence would disappear did we not assume that it is superimposed upon some more fundamental structure, and this is the fundamental structure upon which classifications revealing natural relationships are based, according to Dr. W. T. Calman in his presidential address before the Linnean Society of London (Proc. Linn. Soc. London, 1934-35, p. 145). To illustrate the distinctiveness and significance of the taxonomic view, Dr. Calman traced the parallel between the morphological classification of the higher Crustacea and the evolution of the group. Here is a natural classification which does violence to none of the conclusions of morphology or of palæontology, and is consistent with an evolutionary history in which convergence may have played an important part, but never the dominant one.

\section{Bibliography of Chinese Insects}

THE Journal of the Shanghai Science Institute (Section 3, vol. 2, 1934, pp. 1-533) contains a bulky memoir by Mr. Yoshio Ôuchi entitled "Bibliographical Introduction to the Study of Chinese Insects". It takes the form of a catalogue of references of all systematic, and some other, papers dealing with the insects of China up to the year 1932. It is arranged in taxonomic fashion according to orders, followed, in most groups, by subdivision under the individual families. Facility of reference is thus assured and, it may be added, the work appears to be remarkably complete. An immense number of periodicals in many languages has been explored and the enterprise is one which deserves high commendation. A compilation of this kind will prove of the utmost value in a country far removed from the scientific centres of Western civilisation. In vol. 3, 1935 (pp. 17-88), of the same journal, the author brings this work further up to date in listing all papers of similar bearing published during the year 1933 .

\section{Clothes Moths and House Moths}

THE British Museum (Natural History) has recently issued a second edition of a useful fifty-page pamphlet, entitled "Clothes Moths and House Moths" (British Museum (Natural History), London, S.W.7. 6d.). This pamphlet, which forms No. 14 (Economic Series) of the Museum publications, deals with the five British species of moths found in dwellings, outbuildings, etc., and the larvæ of which are destructive to clothing, blankets, upholstered articles, fur, feathers, etc. Each species is described and its habits explained, and the accounts are accompanied by very clear photographic illustrations. The control of these insects by preventive and remedial measures is fully discussed.

\section{Certification of Blindness}

IT has been found that the results of testing for defective sight by means of test cards may vary according to the degree and standard of illumination of the cards. As the matter is of importance in connexion with certification under the Blind Persons Act, 1920, the Ministry of Health has issued a circular on the subject (Circular 1520. H.M. Stationery Office. 1d. net). This suggests that test cards should pre. ferably be illuminated by artificial light, which should be approximately, and not less than, 10 foot-candles, and a simple means is described for effecting this.

\section{Thomas Gray Memorial Trust Awards for Navigation}

Through the Thomas Gray Memorial Trust, the objects of which are "The advancement of the Science of Navigation and the Scientific and Educational interests of the British Mercantile Marine", the Royal Society of Arts has divided the prize of $£ 100$ offered for an invention, publication, diagram, etc., which constitutes advancement in the science or practice of navigation, between H. J. BuchananWollaston, of Lowestoft, for his current meter, and Dr. F. W. Edridge-Green, of London, for his colour perception lantern, which enables tests to be made under conditions very closely allied to those found in everyday practice, while the colours chosen are those which most rapidly and definitely disclose any defect in colour perception. A prize of $£ 100$ was also offered for an essay on modern navigational appliances made possible by electricity on board, and also appliances not depending on electricity. The prize was divided as follows: $£ 40$ to Lieutenant B. E. Druce, of Salop; $£ 40$ to R. J. Finch, Jr., Second Officer, Royal Mail Lines, Ltd., of Southend-on-Sea; and $£ 20$ to Captain J. G. Bisset.

\section{Solar Eclipse Expeditions}

Two British expeditions to observe the total eclipse of the sun on June 19, 1936, are leaving for sites selected from which to observe the eclipse. The path of the total eclipse stretches from Greece over Siberia to the Pacific Ocean. An expedition led by Prof. F. J. M. Stratton, of the Solar Physics Observatory, Cambridge, will station itself in northern Japan. The programme of eclipse observations consists chiefly of observations of intensities of lines in the flash spectrum; despite the vigorous growth of the technique of spectrophotometry in the last decade, very few spectrophotometric observations have been made on eclipses, chiefly on account of the ill-luck through cloud which has attended recent 